\title{
KORPORASI SEBAGAI PENGEMBAN KEWAJIBAN HAM: SUATU PENCARIAN LEGITIMASI DALAM HUKUM INTERNASIONAL
}

\section{Patricia Rinwigati Waagstein ${ }^{1}$}

\begin{abstract}
Abstrak
In the age of globalization, multinational companies have been playing a major role in economic sector, especially in the current situation where the role of government in the private and public sectors is becoming more limited while independent private enterprise is encouraged. In fact, many public industries and producers as well as public services which were exclusively run by the government have been privatized for the sake of efficiency. Considering corporate role and powers which are obviously increasing, the question is whether it is relevant to impose obligation on corporations to provide justice particularly in term of human rights protection. This article tries to answer such question by searching for theoretical and practical support to impose such duty by using human rights based approach. The focus will be on the debates over the dichotomy of vertical and horizontal applications of human rights. It is concluded in this article that there has been a shift over the development of human right toward the privatisation of human rights.
\end{abstract}

Kata kunci: hukum internasional, korporasi, kewajiban ham, legitimasi

\section{Pendahuluan}

Hak asasi manusia (HAM) pada umumnya ditempatkan dalam ruang lingkup publik yang mengatur hubungan vertikal antara individu sebagai pemegang hak dan pemerintah atau negara sebagai pengemban kewajiban. Sebaliknya, hubungan hukum horisontal antar individu diatur dalam ruang lingkup privat dan oleh karenanya terletak di luar ruang lingkup HAM. Penempatan sifat publik HAM didukung oleh praktek hukum internasional dimana HAM dianggap sebagai produk dari hubungan antar negara-negara yang sering kali dikategorikan sebagai 'hubungan publik'. Lebih lanjut, dalam hukum internasional, hanya negaralah yang dianggap sebagai subjek

${ }^{1}$ Alamat Kontak Penulis: prwaagstein@gmail.com. 
hukum internasional utama yang mempunyai hak dan kewajiban international. Oleh karena itu, instrumen HAM internasional pada umumnya hanya mengikat negara dan bukan institusi lain.

Dalam dua dekade terakhir, para ahli dan aktivis HAM mulai mencoba melakukan terobosan-terobosan baru dengan mengaitkan kegiatan aktor bukan negara (non-state actor) terutama korporasi dengan HAM. Usaha mereka dilatarbelakangi dengan keprihatinan akan semakin banyaknya kasus-kasus pelanggaran HAM yang melibatkan korporasi baik secara langsung atau tidak langsung dan semakin tidak terjangkaunya hukum nasional suatu negara dalam mengatur kegiatan ekonomi mereka yang melintasi batas suatu negara.

Desakan yang sangat kuat dari berbagai pihak telah mendorong berbagai institusi termasuk organisasi international untuk mengambil sikap yang lebih serius terhadap kegiatan ekonomi pelaku bisnis. Organisasi untuk Kerjasama dan Pengembangan Ekonomi (OECD) sudah sejak tahun 1976 mengeluarkan pedoman beroperasi bagi korporasi multinasional (OECD Guidelines for Multinational Enterprises); sementara itu Organisasi Buruh Internasional (ILO) juga telah mengeluarkan Perjanjian Tripartit mengenai Korporasi Multinational (Tritartite Agreement on the Multinational Corporations). Persatuan Bangsa-Bangsa (PBB), setelah melalui studi panjang, mengambil inisiatif untuk menunjuk Prof. Ruggie sebagai perwakilan khusus untuk mempelajari masalah HAM dan Bisnis. Mandat beliau tidak hanya mengklarifikasi seputar keterlibatan korporasi dalam hal pelaksanaan HAM tetapi juga mengumpulkan best practices dari perusahaanperusahaan.

Munculnya gagasan HAM dalam konteks kegiatan ekonomi menimbulkan pertanyaan mendasar yaitu apakah terobosan untuk menghubungkan HAM dengan bisnis mempunyai dasar pembenaran teoritis dan juridis. Apakah pembebanan kewajiban HAM kepada korporasi melanggar teori dasar HAM? Apakah kewajiban tersebut juga melanggar hukum internasional mengingat konsesi pembentukan HAM berakar kuat dalam hukum yang mengatur hubungan antar negara ini? Artikel ini mencoba menjawab pertanyaan-pertanyaan tersebut dengan memaparkan berdebatan hukum mengenai sifat vertikal versus horisontal HAM atau seringkali disebut juga sifat publik versus privat dari HAM. Artikel ini akan menitikberatkan pada dua alasan pembenaran yaitu teoritis dan juridis praktis. Pembenaran teoritis akan membahas bagaimana dikotomi vertikal dan horisontal HAM dipandang dari berbagai teori hukum sementara pembenaran praktis mencoba membahas sejauh mana hukum internasional menanggapi persoalan tersebut. Tujuan akhir dari artikel ini adalah mencoba mengidentifikasi ke arah mana 
perkembangan HAM pada saat ini dan yang akan datang berkaitan dengan masalah bisnis dan HAM.

Ada beberapa klarifikasi yang perlu dijelaskan dalam artikel ini. Pertama, pengertian korporasi dalam artikel ini merujuk pada segala bentuk usaha ekonomi baik yang berbadan hukum atau tidak. Hal ini berbeda dengan pengertian korporasi sebagaimana diatur dalam UU Perseroan Terbatas di Indonesia. Kedua, pengertian HAM di sini adalah hak-hak yang melekat pada diri manusia sejak lahir sebagaimana diatur dalam Deklarasi Umum Hak Asasi Manusia dan instrumen HAM internasional lainnya. Ketiga, analisa yang digunakan dalam artikel ini terbatas pada konstruksi hukum internasional dimana hukum dipandang sebagai suatu proses pengambilan keputusan yang dinamis dengan melibatkan berbagai cabang ilmu hukum dan kebijakan sebagai akibat dari interaksi dari berbagai aktor. ${ }^{2}$ Dalam hal ini, hukum internasional diasumsikan berlaku dan mengikat negara-negara dan dalam batas tertentu aktor lain selain negara berdasarkan sifat dan fungsinya. ${ }^{3}$

\section{Pembahasan}

\section{Pembenaran Teoritis}

\section{Sifat Publik/Vertikalis HAM}

Terlepas dari analisa benar atau salah, pandangan bahwa HAM bersifat publik dan oleh karenanya mengatur hubungan vertikal antara negara dan individu mempunyai dasar hukum yang kuat dalam teori HAM. Pandangan tersebut sangat dipengarui oleh teori kontrak sosial sebagaimana banyak dianut di abad ketujuh dan delapan belas.

Pada awalnya HAM sering dikaitkan dengan teori hukum alam dimana teori ini berpendapat bahwa individu mempunyai hak yang mendasar, universal dan melekat pada kehidupan dan martabat manusia. Oleh karena itu, perlindungan HAM berarti perlindungan terhadap segala bentuk pelanggaran kemanusiaan

${ }^{2}$ Gunther Teubner, "'Global Bukowina: Legal Pluralism in the World Society", Global Law without State, ed. Gunther Teubner (Brookfield: Dartmouth, 1997).

${ }^{3}$ Rosalyn Higgins, "Problems and Process: International Law and How We Use It", (Oxford: Clarendon Press, 1994). 
terlepas dari siapa yang melakukannya. ${ }^{4}$ Dengan kata lain, siapapun dapat melanggar HAM. Pendekatan HAM yang bersifat vertikal mulai mendapatkan tempat dalam karya-karya para penganut kontrak sosial yang menitikberatkan pada kebebasan individu dari negara. Teori hukum ini mewajibkan masyarakat untuk menyerahkan sebagian dari hak-hak yang dimilikinya terutama hak politik kepada negara sementara mereka tetap dapat memegang hak-hak alam (natural rights) mereka seperti hak untuk hidup, hak atas agama atau kepercayaan, hak atas properti dan hak-hak lain dalam bidang ekonomi, sosial, dan budaya. ${ }^{5}$ Akibatnya, perbedaan antara bidang (domain) publik dan privat terbangun. Bidang publik mengatur mengenai hubungan khusus antara masyarakat dengan negara berdasarkan kontrak sosial dimana negara mempunyai kekuasaan yang sah dalam bidang politik. ${ }^{6}$ Sebaliknya, bidang privat terdiri dari hak-hak yang tetap dipegang oleh individu. ${ }^{7}$ Kedua bidang tersebut walaupun terpisah saling melengkapi, namun, jika terjadi perbedaan, hak-hak yang diberikan kepada negara melalui kontrak sosial harus diutamakan. ${ }^{8}$ Akibat dari konstruksi ini adalah negara wajib

${ }^{4}$ Nowak menjelaskan terminilogi perlindungan sebagai 'effective all-round', diskusi lebih lanjut lihat: Manfred Nowak, "Introduction to the International Human Rights Regime", (Leiden, Martinus Nijhoff Publishers, 2003), hal. 51; Evert Albert Alkema, "The Third Party Applicability or 'Drittwirkung' of the European Convention on Human Rights", Protection of Human Rights. The European Dimension, ed. Herbert Petzold Franz Matscher (Berlin: Carl Heymanns Verlag, 1988), hal. 33-35; Erwin Chemerinsky, "Rethingking State Action", Northwestern University Law Review 80.3 (1985), hal. 530.

5 Michael Goodhart, "Human Rights and Non-State Actors", Non-State Actors in the Human Rights Universe, eds. George Andreopoulos, Zehra F. Kabasakal Arat and Peter Juviler, (Bloomfield: Kumarian Press, Inc., 2006), hal. 24.

${ }^{6}$ Hilary Charlesworth, and Christine Chinkin, "The Boundaries of International Law; a Feminist Analysis", (Manchester: Jurist Publishing, Manchester University Press, 2000); Manoj Kumar Sinha, "Enforcement of Economic, Social, and Cultural Rights", (New Delhi: Nice Printing Press, 2006); Danwood Mzikenge Chirwa, "Towards Binding Economic, Social, and Cultural Rights Obligations of Non-State Actors in International and Domestic Law: A Critical Survey of Emerging Norms", Dissertation, University of Western Cape, 2005, hal. 43. hal. 25 .

${ }^{7}$ Hilary Charlesworth, and Christine Chinkin, Op. Cit., : Michael Goodhart, Op. Cit.,

${ }^{8}$ Manoj Kumar Sinha, "Enforcement of Economic, Social, and Cultural Rights", (New Delhi, Nice Printing Press, 2006); Michael Goodhart, "Human Rights and Non-State Actors: Theoritical Puzzles", Non-State Actors in the Human Rights Universe, eds. George 
melindungi setiap hak dalam bidang publik atau privat namun dalam bentuk yang berbeda tergantung dari jenis hak-haknya. Hak-hak sipil dan politik yang diserahkan kepada suatu negara memerlukan campur tangan langsung dari negara sementara hakhak ekonomi, sosial dan budaya yang berada dalam kapasitas individu dianggap tidak membutuhkan campur tangan negara. ${ }^{9}$ Oleh karena itu, tugas pemerintah hanya sebagai pengawas (to police) HAM tetapi bukan penjamin sandang, pangan, dan papan.

Berdasarkan penjelasan tersebut, teori sosial kontrak dapat dianggap sebagai penyebab utama dari berlakunya sifat publik HAM. Namun, batas pemisah antara sifat privat dan publik semakin pudar sejalan dengan semakin diterimanya beberapa pandangan seperti Marxist, feminism, dan komparasi budaya terhadap HAM (inter-cultural perspectives) yang menyoroti unsur horisontal HAM.

Namun, sebelum beranjak pada teori hukum yang memasukkan unsur horisontal dalam HAM, ada satu teori hukum yang patut untuk dibahas yaitu posivitism. Menurut teori hukum ini, HAM adalah 'what the law says (lex lata), and not what the law should be (lex ferenda)'. ${ }^{10}$ HAM bukan sesuatu yang melekat pada manusia secara langsung (inherent) tetapi diberikan oleh negara melalui penetapan hukum. Oleh karenanya isi dan bentuk HAM bersifat relatif tergantung dari negara yang mengadopsinya. ${ }^{11}$ Hal ini menimbulkan ambiguitas mengenai posisi dari teori hukum positivism dalam hal dikotomi publikprivat. Di satu sisi, negara dapat menentukan bahwa HAM bersifat publik dan oleh karenanya hanya mengatur hubungan antara negara dan individu dimana negara berperan sebagai pengemban kewajiban HAM dan individu adalah pemegang HAM. Namun di

Andreopoulos, Zehra F. Kabasakal Arat and Peter Juviler (Bloomfield: Kumarian Press, Inc, 2006), hal. 25.

9 Danwood Mzikenge Chirwa, Towards Binding Economic, Social, and Cultural Rights Obligations of Non-State Actors in International and Domestic Law: A Critical Survey of Emerging Norms, Dissertation, University of Western Cape, 2005, hal. 43.

${ }^{10}$ Manoj Kumar Sinha, Op. Cit., hal. 10.

${ }^{11}$ Dauglas Hodgson, "Individual Duty within a Human Rights Discourse", (Ashgate, 2003), hal. 7; Manoj Kumar Sinha, "Enforcement of Economic, Social, and Cultural Rights", (New Delhi: Nice Printing Press, 2006), hal. 10; Henry J. Steiner, Philip Alston, and Ryan Goodman, "International Human Rights in Context: Law, Politics, Morals: Text and Materials", 3th ed. (Oxford: Oxford University Press, 2008), hal. 478. 
sisi lain, negara juga dapat menetapkan kewajiban HAM kepada aktor lain selain negara sepanjang hal tersebut diatur dalam peraturan perundangan dari negara yang bersangkutan. Konstitusi Afrika Selatan dan Konstitusi Jerman, sebagai contoh, secara jelas mengakui aplikasi horisontal HAM dimana hubungan privat antar individu dapat juga dikategorikan sebagai bagian dari HAM. Dengan kata lain, setiap individu mempunyai hak sekaligus kewajiban terhadap HAM. ${ }^{12}$ Ini berarti pelanggaran HAM dapat dilakukan oleh negara maupun aktor lain selain negara. Berbeda dengan UU HAM Kanada yang hanya membatasi perlindungan HAM dalam kerangka vertikal yaitu antara individu sebagai pemegang hak dan negara sebagai pengemban kewajiban HAM. ${ }^{13}$ Dengan demikian hanya negara yang dapat melakukan pelanggaran HAM.

\section{Sifat Privat HAM}

Sifat publik HAM banyak digugat oleh berbagai teori hukum seperti Marxism, Feminism dan Perbandingan Budaya (cross cultural perspective). Ketiga teori ini mempunyai pengaruh yang kuat terhadap perkembangán HAM terutama berkaitan dengan pelanggaran HAM oleh aktor bukan negara.

\section{a. Socialism/Marxism}

Kritik dari Marxism terhadap HAM terletak pada ide bahwa HAM (sering kali disebut: hak manusia atau the rights of man) hanya melayani kepentingan penguasa dan HAM digunakan untuk melegitimasi perbedaan ekonomi dan perbedaan sistematis lainnya dalam wacana privat. ${ }^{14}$ Menurut teori ini, kedudukan individu tidaklah sejajar dan semandiri sebagaimana dianut oleh hukum alam karena perbedaan keadaan sosio-ekonomis dari

${ }^{12}$ Constitution of the Republic of South Africa No. 108 of 1996. 1996, Chapter 2, Pasal 8, para (2); Woolman, Stuart, "Application", Constitutional Law of South Africa, eds. Matthew Chaskalson Jenet Kentridge, Jonathan Klaaren, Gilbert Marcus, Derek Spitz and Stuart Woolman, $1^{\text {st }}$ ed. (Cape Town: Juta \& Co. Ltd, 1999).

${ }^{13}$ Danwood Mzikenge Chirwa, Op. Cit., hal. 50.

${ }^{14}$ Ibid., hal. 54 . 
masing-masing individu. ${ }^{15}$ Akibatnya, konsep-konsep umum seperti keadilan, demokrasi, dan hak-hak manusia menjadi sangat relatif karena ditentukan oleh kondisi materi dan sosial dari masing-masing individu dan kelompok. Apabila kondisi sosial dan materi mereka berubah, maka berubah pula konsep-konsep tersebut. Hal ini menunjukkan bahwa konsep hak-hak manusia tidak absolut melainkan bersifat individualistik, berpusat pada materi, dan sangat subjektif sebagaimana diutarakan oleh Marx dalam karyanya: On the Jewish Question. ${ }^{16}$

Sebagai protes atas perbedaan kelas, sosialism mendukung persamaan dalam segala lapisan masyarakat dan solidaritas dari seluruh anggota masyarakat. ${ }^{17}$ Dalam hal ini, sosialism menganggap manusia bukanlah mahluk egoistik sebagaimana dianut oleh teori hukum alam melainkan kolektif dimana kepentingan mereka tergantung kepada dan berada dibawah subordinasi masyarakat dan negara. ${ }^{18}$ Oleh karena itu, perbedaan kelas harus dihapuskan dan kekuasaan, kekayaan, serta ilmu pengetahuan harus didistribusikan secara merata ke seluruh masyarakat. Lebih lanjut, hak-hak individu harus selalu dikaitkan dengan kewajiban individu contohnya: kewajiban terhadap properti dikaitkan dengan hak terhadap properti. ${ }^{19}$ Akibatnya, di samping hak-hak individu yang ditentukan oleh negara, individu juga mempunyai kewajiban terhadap masyarakat. ${ }^{20}$ Kewajibankewajiban tersebut bersifat netral dan berlaku bagi setiap orang

${ }^{15}$ Manoj Kumar Sinha, Op. Cit., hal. 12.

${ }^{16}$ Karl Marx, "On the Jewish Question", Deutsch-Französische Jahrbücher (1844). It is cited in Dembour, Marie-Bénédicte, Who Believes in Human Rights? Reflections on the European Conventions (Cambridge: Cambridge University Press), hal. 114; Hayden, Patrick, "The Philosophy of Human Rights", (St. Paul: Paragon House, 2001), hal. 131.

17 Gunther Teubner, The Anonymous Matrix: Human Rights Violations by 'Private' Transnational Actors, The Modern Law Review 69.3, hal. 331.

${ }^{18}$ Karl Marx, "Critique of Hegel's Philosphy of Rights", trans. Annette Jolin and Joseph O'Malley, ed. Joseph O'Malley, (Cambridge: Cambridge University Press, 1943-44 (written) \& 1970 (published)).

19 Aryeh L Unger, "Constitutional Development in the Ussr: A Guide to the Soviet Constitutions", (London: Methuen, 1984), hal: 274.

${ }^{20}$ David Kelley, "A Life of One's Own: Individual Rights and the Welfare State", (Cato Institute, 1998), hal. 17. 
tanpa memandang kelas. ${ }^{21}$ Dalam hal ini, negara diwajibkan untuk mengawasi pelaksaaan hak dan kewajiban di seluruh bidang baik sosial, legal maupun politik untuk kepentingan bersama. Salah satu implikasi dari kerangka hukum ini adalah perbedaan publik atau privat hak-hak manuasia tidak lagi relevan karena perbedaan struktural antara masyarakat menjadi tidak jelas. ${ }^{22}$

\section{b. Teori Hukum Feminism}

Teori hukum lain yang juga menolak perdebatan dikotomi publik- privat HAM adalah feminism. Teori hukum ini berargumentasi bahwa kategorisasi sifat publik dari HAM justru akan menguntungkan kaum adam karena melindungi mereka (dan aktor-aktor lain selain negara) dari pertanggungjawaban HAM atas kekerasan yang mereka lakukan terhadap anak-anak dan perempuan dalam ruang lingkup domestik/privat. ${ }^{23}$ Menurut paham ini, di ruang publik, HAM berlaku, sementara di ruang privat HAM tidak berlaku. ${ }^{24}$ Sebagai akibatnya, kekerasan yang terjadi antara individu tidak dapat dianggap sebagai pelanggaran HAM karena berada diluar ruang lingkup hubungan antara negara dan individu (publik). Contoh-contoh nyata seperti perkosaan dalam perkawinan, kekerasan dalam rumah tangga dan diskriminasi dalam hal pekerjaan, pendidikan, kesehatan dan pelayanan sosial yang berada di luar jangkauan negara dapat mengarah pada impunitas pelanggaran HAM. Keadaan dipersulit dengan fakta bahwa beberapa pelayanan seperti pelayanan kesehatan yang telah diprivatisasi mengakibatkan diskriminasi ganda: diskriminasi terhadap hak-hak perempuan dan diskriminasi akibat privatisasi. ${ }^{25}$ Akibatnya, posisi perempuan lebih tersingkir

${ }^{21}$ M.D.A. Freeman, "Lloyd's Introduction to Jurisprudence", 7th ed. (London: Sweet \& Maxwell, 2001), hal. 970.

${ }^{22}$ Danwood Mzikenge Chirwa, Op. Cit., hal. 56.

${ }^{23}$ Jan Arno Hessbruegge, Human Rights Violations Arising from Conduct of Non-State Actors, Buffalo Human Rights Law Review 11.21 (2005), hal. 27.

${ }^{24}$ Hilary Charlesworth, and Christine Chinkin, Op. Cit., hal. 56.

${ }^{25}$ Sebagaimana diutarakan oleh Clapham, privatisasi pelayanan kesehatan biasanya diikuti oleh pengurangan subsidi dari pemerintah. Hal ini mengakibatkan suatu keluarga dihadapkan pada pilihan siapa yang harus dibiayai apabila beberapa anggota keluarga sakit. Banyak kasus menyatakan bahwa pilihan banyak diberikann kepada anggota laki-laki daripada 
lagi karena ketidakmampuan mereka untuk melaksanakan hak-hak dasar mereka.

Oleh karena itu, pendekatan feminism menolak keras pemisahan yang absolut antara ruang publik dan privat. Kritik tersebut tidak dimaksudkan untuk menghapuskan pembagian ruang publik dan privat sehingga tercipta suatu pandangan monolitik sehubungan dengan isu-isu perempuan. Sebaliknya pendekatan ini mengusulkan suatu pembagian bidang privatpublik yang dinamis dan fleksibel sehingga dapat disesuaikan dengan doktrin hukum yang berlaku dan kebutuhan di lapangan. ${ }^{26}$ Fleksibilitas dikotomi tersebut sangat diperlukan dalam isu-isu perempuan yang sebagian besar berada di 'grey area' antara ruang privat dan publik.

\section{c. Pendekatan Komparasi Budaya (Cross Cultural Perspective)}

Pendekatan lain yang juga mengkritisi sifat publik HAM terlihat dalam pendekatan komparasi budaya. Pendekatan yang banyak menyoroti perdebatan antara konsep universalm versus relativism dari HAM ini mengakui bawah perbedaan budaya dan politik dapat mempengaruhi konsep HAM paling tidak dalam skala implementasi. ${ }^{27}$ Namun, sampai sejauh mana implikasi dari pengaruh perbedaan budaya dan politik tersebut masih diperdebatkan. Lebih lanjut, salah satu isu yang paling diperdebatkan dalam konteks universalm versus relativism dari HAM ini adalah sifat individualistik versus komunitarian dan sayangnya sampai saat ini tidak ada suatu kesepakatan yang jelas mengenai apakah sifat HAM adalah individualik atau komunitarian sehingga pembahasan pada umumnya dilakukan kasus per kasus.

Dalam konteks Afrika, Chirwa berpendapat bahwa konsep HAM di Afrika lebih bersifat komunitarian dalam arti perlindungan HAM didasarkan pada status keanggotaan dalam

perempuan mengingat tanggungjawab anggota keluarga laki-laki sebagai kepala keluarga atau calon kepala keluarga. Pembahasan lebih lanjut lihat: Andrew Clapham, "Human Rights Obligations of Non-State Actors", (Oxford: Oxford University Press, 2006).

${ }^{26}$ Hilary Charlesworth, and Christine Chinkin, Op. Cit., hal. 59.

27 An-Na'im, Abdullahi Ahmed, "Conclusion, Human Rights in Cross-Cultural Perspective: A Quest for Consensus", ed. Abdullahi Ahmed An-Na'im (Pennyslvania: University of Pennsylvania Press, 1995), hal. 427. 
masyarakat dan kesejahteraan masyarakat dianggap sebagai tujuan dari pelaksanaan HAM. ${ }^{28}$ Oleh karena itu, hak tidak dapat dipisahkan dari kewajiban terhadap masyarakat. ${ }^{29}$ Alasan utama dibalik hubungan timbal balik antara individu dan kelompok masyarakat tersebut adalah adanya praktek kolonialisme di Afrika disamping faktor-faktor lainnya.

Tidak berbeda dengan Afrika, Xiaorong Li, ketika mengomentari Asian Values, menekankan pada 'asia communitarianism' yang berakar pada tradisi agama seperti: Konfusius, Budha, Hindu, Islam dan lain-lain yang kemudian dimodifikasi oleh budaya setempat. ${ }^{30}$ Menurut beliau, masyarakat Asia berpandangan bahwa mereka mempunyai tanggung jawab atas kelangsungan hidup dan keamanan dari anggota masyarakatnya. Tanpa tanggungjawab tersebut, menurut Li, tidak akan ada martabat manusia. ${ }^{31}$ Dalam hal ini, hak dan kewajiban tidak selalu diformulasikan sebagai hak dan kewajiban hukum tetapi hak dan kewajiban tersebut berada dan melekat pada masyarakat.

Sifat komunitarian dari masyarakat di Asia dikonfirmasikan oleh pemerintah China, Singapura, Malaysia, dan Indonesia dalam konferensi Bangkok dimana masing-masing negara berbicara tetang warisan budaya dan nilai-nilai yang menekankan pada kewajiban komunitarian warganya terhadap masyarakat. Negaranegara ini juga menyatakan bahwa interpretasi, pelaksanaan, dan pemantauan hak-hak dan kewajiban berada dalam lingkup negara.

Berkaitan dengan masyarakat Eropa, Prof. Adamantia Pollis berpendapat bahwa aspek individualisme yang dianut dalam konsep HAM di Eropa berakar dari pandangan HAM yang lebih menitikberatkan pada hak-hak sipil dan politik. ${ }^{32}$ Beliau mengkritik para pemikir liberal barat yang mengabaikan fakta

${ }^{28}$ Danwood Mzikenge Chirwa, Op. Cit., hal. 74.

${ }^{29}$ Ibid.

${ }^{30}$ Adamantia Pollis, "Cultural Relativism Revisited: Through a State Prism", Human Rights Quarterly 18.2 (1996), hal. 335.

${ }^{31}$ Patrick Hayden, "The Philosophy of Human Rights", (St. Paul: Paragon House, 2001), hal. 402 .

32 Adamantia Pollis, Op. Cit., hal. 319. 
bawah sebelum munculnya kapitalisme di barat, hak-hak ekonomi dan sosial yang menitikberatkan pada masyarakat komunitarian telah dianut meskipun dalam pengaturan komunal yang feodal.

Ada dua hal yang patut dicermati dari perdebatan para ahli dalam konteks perbandingan budaya: Pertama, sifat komunitarian dari HAM telah lama dianut. Konsep komunitarian maupun individualistik dari HAM bersifat dinamis dan perkembangannya sangat dipengaruhi oleh kondisi historis dan sosial dari masyarakat pada suatu masa. Kolonialisme dan modernisasi adalah salah satu faktor penggerak utama peralihan dari sistem HAM yang komunitarian ke individualistik. Namun, Pollis tetap beranggapan bahwa munculnya kembali perdebatan soal komunitarialisme sejalan dengan mulai dikembangkannya hakhak ekonomi, sosial, dan budaya. Hak-hak tersebut membutuhkan suatu parameter yang didefinisikan bersama oleh seluruh anggota masyarakat. Hal ini menjadi suatu kewajiban dari setiap elemen masyarakat untuk menjamin kelangsungan hidup dan keamanan dari setiap anggotanya. ${ }^{33}$ Akibatnya, sebagai anggota masyarakat, individu mempunyai kewajiban terhadap keluarga, masyarakat dan negara dimana dia berada.

Kedua, apakah badan hukum juga mempunyai kewajiban serupa? Diskusi diatas menyatakan bahwa walaupun masyarakat pre-kolonial belum mengenal konsep badan hukum sebagaimana dianut dalam pengertian modern, dengan diberikannya kategori subjek hukum terhadap korporasi maka korporasi dapat dianggap sebagai individu yang juga mempunyai hak dan kewajiban dalam masyarakat dimana dia melakukan kegiatan ekonomi.

\section{Apakah Kewajiban Individu Atau Aktor Bukan Negara Melanggar Teori HAM?}

Dari diskusi diatas dapat ditarik kesimpulan bahwa kewajiban individu bukanlah suatu konsep baru namun telah berakar dalam perkembangan sejarah perkembangan HAM. Oleh karena itu anggapan bahwa hanya negara yang mempunyai

${ }^{33}$ Pollis Adamantia, "Towards a New Universalism: Reconstruction and Dialogue", Netherland Quarterly of Human Rights 16.1 (1998), hal. 15; Danwood Mzikenge Chirwa, Op. Cit., hal. 77. 
kewajiban untuk melindungi dan melaksanakan HAM tidak dapat dipertahankan. Kewajiban aktor lain selain negara untuk melindungi dan melaksanakan HAM mempunyai dasar pembenar baik secara historis maupun teoritis.

Dari beberapa teori hukum yang dibahas sebelumnya, teori kontrak sosial meletakan basis teoritis terhadap dikotomi publik dan privat dimana HAM termasuk di dalam ruang publik dan oleh karenanya konsep HAM hanya mengatur hubungan antara individu dan negara. Sementara teori hukum positivis bersifat dualisme dimana teori ini dapat dianggap mendukung atau menolak dikotomi tersebut. Sebaliknya, teori hukum sosialisme/ Marxisme dan feminism mendukung dilakukannya revisi terhadap dikotomi tersebut. Revisi tersebut sangat dibutuhkan terutama untuk menjangkau kekerasan atau pelanggaran HAM yang dilakukan dalam ruang lingkup privat. Pada akhirnya, suatu model horisontal HAM yang mewajibkan setiap aktor untuk melindungi HAM harus dikembangkan. Pendekatan perbandingan budaya memberikan bukti sosiologis tambahan bahwa individu tidak bebas dari kewajiban mereka terhadap keluarga, masyarakat, dan negara.

Namun demikian, ada beberapa catatan yang harus diperhatikan dalam menerapkan kewajiban HAM: Pertama, penekanan adanya kewajiban individu terhadap HAM tidak dapat dijadikan persyaratan untuk mendapat HAM. Dengan kata lain lain, kewajiban dan hak harus dilakukan bersamaan. Kedua, sifat horisontal HAM tidak berarti bahwa setiap mahluk privat mempunyai kewajiban yang sama seperti negara. Dalam hal ini perlu ditegaskan bahwa pemberikan kewajiban perlindungan HAM kepada individu atau badan hukum bukan berarti telah terjadi pengalihan tanggung jawab dari negara ke institusi lain. Setiap institusi baik negara atau bukan mempunyai kewajiban terhadap HAM sesuai dengan peran dan fungsinya masingmasing. Ketiga, berkaitan dengan dikotomi privat-publik atau horisontal-vertikal, kritik terhadap sifat publik HAM tidak berarti bahwa pendapat ini menginginkan dihapuskannya perbedaan antara publik dan privat, meskipun perbedaan itu di banyak kasus tidak dapat dipertahankan. Sebaliknya kritik tersebut menyatakan bahwa HAM tidak hanya menyangkut masalah publik tapi juga privat. Lebih jauh kritik dalam hal ini ingin menitikberatkan pada pandangan bahwa dikotomi publik-privat atau horisontal-vertikal dari HAM tidak dapat dijadikan suatu faktor utama dalam 
menentukan apakah negara perlu turut campur atau tidak dalam suatu masalah atau apakah institusi lain harus tunduk pada ketentuan HAM atau tidak. Argumentasi di sini bersifat metodologis yaitu bahwa pengadilan atau institusi yang berwenang tidak boleh menolak kasus-kasus pelanggaran HAM oleh individu atau badan hukum hanya berdasarkan 'an absence of government involvement'.

\section{Pendekatan Juridis Praktis}

Didasarkan pada pembentukan dan applikasinya, hukum internasional publik pada umumnya dikaitkan dengan hukum yang mengatur hubungan antara negara. Pertanyaannya adalah apakah sumber-sumber hukum internasional terutama berkaitan dengan HAM dapat juga diberlakukan terhadap aktor lain termasuk korporasi walaupun aktor-aktor ini tidak menjadi 'pihak' dalam perjanjian HAM dan berada diluar ruang lingkup pembentukan sumber-sumber hukum lainnya seperti kebiasaan internasional namun mereka mempunyai kepentingan dan pengaruh terhadap perkembangan HAM. Untuk menjawab pertanyaan tersebut, perlu adanya investigasi terhadap beberapa sumber hukum HAM internasional Jawaban atas pertanyaan tersebut menjadi sangat penting untuk menyimpulkan apakah aplikasi horizontal HAM hanya mencapai tataran konsep atau juga telah diaplikasikan dalam hukum internasional.

\section{Jus Cogens dan Kebiasaan Internasional}

Isu apakah HAM secara keseluruhan merupakan norma hukum kebiasaan dan atau jus cogens selalu mengundang perdebatan dan selama ini belum ada kata sepakat diantara para ahli mengenai hal tersebut. Hal ini disebabkan karena kesimpang-siuran kriteria terbentuknya kebiasaan internasional dan jus cogens serta variasi perkembangan masing-masing hak, sehingga investigasi apakah HAM merupakan hukum kebiasaan internasional atau jus cogens tidak dapat digeneralisir melainkan harus dilakukan kasus per kasus. Walaupun demikian, fakta bawah beberapa hakhak tertentu seperti hak terlepas dari perbudakan, hak untuk hidup, dll telah diterima sebagai norma kebiasaan internasional. 
Peranan hukum kebiasaan internasional dan jus cogens sangat besar dalam perkembangan HAM pada umumnya. Sehubungan dengan jus cogens, setiap perjanjian atau persetujuan yang melanggar norma jus cogens harus batal demi hukum karena sifatnya yang universal dan absolut. ${ }^{34}$ Sementara itu, dalam hal hukum kebiasaan internasional, seluruh negara harus mentaatinya terlepas dari apakah negara tersebut menyetujui atau tidak sepanjang negara tersebut tidak menentangnya secara konsisten pada saat proses pembentukan hukum kebiasaan internasional dimulai.

Pertanyaannya adalah apakah hukum kebiasaan internasional mengikat aktor-aktor lain selain negara terutama korporasi. Dalam kasus Rache $G m b H \&$ Co versus Hauptzollant Mainz, Mahkamah Eropa (European Court of Justice) menyatakan: '...the European Community must respect international law in the exercise of its powers. It is thus required to comply with the rules of customary international law when adopting a regulation suspending the trade concessions granted by, or by virtue of, an agréement which it has concluded with a non-member country. ${ }^{35}$ Dengan kata lain, Komunitas Eropa sebagai suatu organisasi internasional tidak luput dari kewajiban untuk tunduk dan mentaati hukum kebiasaan internasional.

Berlakunya kebiasaan internasional dan jus cogens terhadap aktor lain selain negara dikonfirmasikan lebih lanjut dalam kasus Comunidades Jiguamiando dan Juridical Condition and Rights of the Undocumented Migrants di Pengadilan HAM Inter-Amerika. Meskipun kedua kasus tersebut berbeda dalam konteks dan sifat, keduanya mempunyai persamaan yaitu mengakui berlakunya applikasi horisontal dari HAM dimana seluruh pihak mempunyai kewajiban untuk tunduk dan mentaati jus cogens dan hukum kebiasaan. Pernyataan serupa diberikan oleh Pengadilan Pidana Internasional untuk bekas Jajahan Yugoslavia (ICTY) terutama dalam kasus Prosecutor v. Anto Furundzija dimana hakim menyatakan bahwa larangan penyiksaan adalah norma absolut (peremptory norm) yang tidak dapat dilanggar oleh siapapun baik

${ }^{34}$ Vienna Convention on the Law of Treaties. Adopted on 22 May 1969, entry into force on 27 January 1980.

${ }^{35}$ ECJ, Rache GmbH \& Co. v. Hauptzollant Mainz, 16 June 1998, Paragraph 45. 
negara maupun individu. Namun, kewajiban antara individu dan negara dalam hal ini dibedakan. Kewajiban negara dalam hal penyiksaan tidak hanya berupa kewajiban negatif tetapi juga positif. ${ }^{36}$ Kewajiban negatif berarti negara tidak dapat melanggar jus cogens dan norma kebiasaan hukum internasional sedangkan kewajiban positif menuntut negara untuk mengadopsi normanorma hukum kebiasaan dan jus cogens ke dalam hukum nasionalnya termasuk membatalkan dan mengamandemen semua perundang-undangan, tindakan administrasi dan judiris yang menghalalkan penyiksaan. ${ }^{37}$ Sebaliknya, kewajiban individu atau aktor lain terbatas pada kewajiban negatif dimana mereka dilarang untuk melakukan dan atau ikut serta melakukan penyiksaan. Pertanggungjawaban individu sangat erat berhubungan dengan pertanggungjawaban negara dimana pertanggung jawaban individu menuntut negara untuk mengadili dan menghukum mereka yang berpartisipasi dalam kegiatan penyiksaan.

Bagaimana dengan korporasi? Dapatkan perusahan melakukan penyiksaan? Walaupun belum ada kasus penyiksaan yang secara khusus melibatkan perusahaan, dapat disimpulkan bahwa perusahaan pun tidak luput dari norma kebiasaan internasional. Hal ini dapat terlihat dari berbagai kasus-kasus Nazi yang melibatkan korporasi seperti kasus Amerika Serikat $v$. Fredrick Flick, et.all, USA v. Carl Krauch, et.al, dan USA v. Farben dimana korporasi juga kewajiban untuk menghormati dan mentaati norma-normal jus cogens dan hukum kebiasan internasional. Hanya saja, selama ini pertanggungjawabannya dilakukan oleh direksi atau pemilik korporasi sebagai pertanggungjawaban individu dan bukan perusahaan.

\section{Perjanjian Internasional/Konvensi Internasional}

Apakah suatu perjanjian intenasional berlaku juga untuk aktor lain selain negara yang notabene adalah bukan pihak dalam perjanjian internasional? Dalam hal ini ada beberapa konstruktif yang dapat digunakan untuk menjawab pertanyaan tersebut:

36 Trial Chamber II International Tribunal for Yugoslavia, Prosecutor V. Anto Furundzija, Case No. IT-95-17/1, Judgment of 10 December 1998, 1998, para. 155.

${ }^{37}$ Ibid. 


\section{a. Pendekatan Langsung (Direct) dan Tidak Langsung (Indirect)}

Pendekatan ini mendasarkan pada perbedaan yang tegas antara hukum nasional dan hukum internasional dimana hukum internasional hanya mengatur mengenai hubungan negara. Oleh karenanya hukum internasional hanya dapat diberlakukan secara tidak langsung terhadap individu atau institusi di dalam suatu negara termasuk korporasi melalui hukum nasionalnya. Dengan demikian, instrument HAM baru dapat diberlakukan terhadap korporasi apabila instrument tersebut sudah diadopsi ke dalam hukum nasional negaranya.

Sayangnya, pembagian 'langsung' atau 'tidak langsung' dalam hukum internasional tidak selalu mudah dilakukan. Hal ini terlihat dalam kerangka HAM dimana individu atau kelompok juga mempunyai akses langsung dalam dunia internasional. Mereka dapat menyampaikan keberätan langsung berdasarkan hukum internasional kepada pengadilan-pengadilan HAM internasional seperti Pengadilan HAM Eropa, pengadilan HAM Inter-Amerika, Komite HAM, Komite HAM Afrika tanpa melalui perwakilan negara walaupun untuk mendapatkan akses tersebut disyaratkan adanya ratifikasi dari negara yang bersangkutan. Akses tersebut juga dapat dinikmati oleh korporasi dalam mekanisme HAM Eropa terutama dalam kaitannya dengan hak atas properti dan hak atau kebebasan dalam hal ekonomi dimana korporasi dapat mengajukan keberatan ke Pengadilan HAM Eropa apabila hak-hak mereka dilanggar. ${ }^{38}$ Contoh lain juga terdapat dalam hukum pidana internasional dimana seseorang dapat dimintakan pertanggungjawabannya langsung di hadapan Mahkamah Pidana International (International Criminal Court) karena pelanggaran Statuta Roma. Aplikasi langsung atau tidak langsung adalah suatu aplikasi yang relatif yang bersandarkan pada sifat, tujuan, dan konteks dari masing-masing perjanjian internasional: Dengan demikian sukar untuk menyandarkan kriteria apakah perjanjian hukum internasional berlaku terhadap

${ }^{38}$ Pasal 34 dari Protocol No. 11 dari Konvensi HAM Eropa menyatakan: '[European Court of Human Rights] may receive applications from any person, non-governmental organisations or group of individuals claiming to be the victim of a violation by one of the High Contracting Parties of the rights set forth in the Convention or the protocols thereto'. Pembahasan lebih lanjut: Marius Emberland, "The Human Rights of Companies: Exploring the Structure of Echr Protection", (Oxford: Oxford University Press, 2006), hal. 14 - 17. 
korporasi atau tidak hanya berdasarkan 'pendekatan langsung atau tidak langsung'.

Lebih lanjut konsep 'langsung' atau 'tidak langsung' sering diasosiasikan dengan perbedaan praktek negara-negara dalam memberlakukan hukum internasional. Sebagian negara menganut asal monoism atau self-executing atau langsung dimana perjanjian internasional dianggap sebagai hukum nasional dan berlaku secara langsung terhadap warganegaranya. Sebagian negara lain menganut asas dualism atau tidak langsung dimana dibutuhkan suatu tindakan khusus untuk mengadopsi hukum internasional ke dalam hukum nasional. Namun pembedaan tersebut tidak absolut karena banyak negara-negara yang mengadopsi prinsip-prinsip dalam hukum internasional ke dalam hukum negaranya atau ke dalam putusan pengadilan nasionalnya tanpa meratifikasi konvensi tersebut. Dalam kasus ini, doktrin monoism atau dualism menjadi konsep yang prosedural daripada substantif. Sehingga, walaupun suatu negara tidak meratifikasi konvensi HAM, kesempatan tetap terbuka untuk memberlakukan hukum internasional terhadap individu atau institusi dari suatu negara minimal secara substantif.

\section{b. Ada atau Tidaknya Mekanisme untuk Melaksanakan Kewajiban HAM}

Pada saat ini, mekanisme HAM yang tertuang dalam berbagai perjanjian internasional pada umumnya menitikberatkan pada pertanggungjawaban negara dan bukan aktor-aktor lain. Akses terhadap aktor bukan negara biasanya dilakukan dalam kerangka nasional. Hal ini lah yang sering digunakan oleh para ahli untuk menyatakan bahwa korporasi atau aktor lain tidak terikat pada perjanjian HAM. ${ }^{39}$ Dengan kata lain, keberadaan mekanisme pertanggungjawaban dijadikan sebagai suatu indikasi berlaku atau tidaknya aplikasi horisontal HAM bagi korporasi. Walaupun pendapat tersebut menyiratkan kenyataan dimana belum ada satu konvensi HAM yang meminta pertanggung jawaban HAM korporasi, pendapat tersebut mengabaikan kenyataan lain bahwa pelaksanaan norma-norma HAM (enforceability) dapat selalu dilaksanakan di tingkat nasional.

39 Evert Albert Alkema, "The Third Party Applicability or 'Drittwirkung' of the European Convention on Human Rights", Protection of Human Rights. The European Dimension, ed. Herbert Petzold Franz Matscher (Berlin: Carl Heymanns Verlag, 1988). 
Dengan demikian tidak adanya mekanisme HAM bagi aktor bukan negara di tingkat internasional tidak menutup kemungkinan untuk diberlakukannya HAM terhadap aktor lainnya pada tingkat nasional berdasarkan hukum internasional. Dalam hal ini, hukum nasional dan hukum internasional saling melengkapi satu sama lain.

\section{c. Mekanisme Interpretasi}

Metode lain untuk melihat apakah perjanjian HAM internasional berlaku juga terhadap korporasi adalah berdasarkan interpretasi tekstual dari perjanjian tersebut. Untuk itu ada beberapa konstruksi yang perlu dicermati: Pertama, berdasarkan pada rumusan atau terminologi yang digunakan, istilah 'corporation' atau 'entity' hanya digunakan dalam beberapa perjanjian internasional. ${ }^{40}$ Sebaliknya, hampir semua perjanjian internasional dalam bidang HAM menggunakan istilah yang umum yaitu: 'individual', 'person', atau 'people' atau 'organ of society.' Hal ini terlihat dalam Paragrah 8 dari Mukadinah DUHAM, Paragrah 5 dari Mukadinah Kovenan Sipil dan Politik serta Kovenan Ekonomi, Sosial, dan Budaya: 'Realizing that the individual, having duties to other individuals and to the community to which he belongs, is under a responsibility to strive for the promotion and observance of the rights recognized in the present Covenant...' Ekspresi yang sama ditemukan dalam pasal 5 dari kedua kovenan:

Nothing in the present Covenant may be interpreted as implying for any State, group or person any right to engage in any activity or to perform any act aimed at the destruction of any of the rights or freedoms recognized herein, or at their limitation to a greater extent than is provided for in the present Covenant.

Kedua bagian ini dianggap sebagai referensi langsung kewajiban aktor bukan negara termasuk individu dan kelompok, untuk mempromosikan dan melaksanakan hak-hak yang diakui oleh instrumen ini. Pertanyaannya adalah apakah terminologi tersebut dapat diinterpretasikan sedemikian rupa sehingga

${ }^{40}$ Convention on the Elimination of All Forms of Discrimination against Women. Adopted by the General Assembly of the United Nations on 18 December 1978 and entered into force on 3 September 1981, Pasal 2 para (e) \& pasal 4. 
termasuk korporasi. Salah satu caranya adalah dengan mengasumsikan korporasi sebagai bagian dari 'individual' atau 'organ of society' sebagaimana sering digunakan dalam treaty bodies dan special rapporteurs. Hal tersebut terlihat jelas dalam general comments dari Komite Ekonomi, Sosial, dan Budaya no. 15 mengenai hak atas air, no. 14 mengenai hak atas kesehatan, dan no. 12 mengenai hak atas pangan dimana interpretasi organ of society termasuk juga institusi privat atau juga korporasi.

Metode lain untuk membaca instrument HAM internasional adalah dengan mengasumsikan bahwa perumusan hak yang menekankan pada pemegang hak ('every one has a right... ) dengan tidak disertasi oleh penekanan pada pengemban kewajiban dapat diartikan memberikan kewajiban HAM kepada negara maupun aktor lain. Permasalahan timbul berkaitan dengan perumusan yang terdapat dalam Kovenan Ekonomi Sosial dan Budaya dimana kovenan itu memulai perumusan dengan pernyataan: 'States party to the present Covenant recognise...' Apakah kovenan tersebut dapat diinterpretasikan memberikan kewajiban kepada korporasi mengingat aktivitas korporasi sangat berkaitan erat dengan perlindungan hak atas pangan, papan, dan hak-hak lainnya? Dalam hal ini perlu adanya pembuktian berdasarkan interpretasi yang lazim berlaku dalam konteks HAM. Banyak treaty bodies melalui general comments atau pun rekomendasinya secara jelas menyatakan bahwa korporasi harus tunduk pada ketentuan HAM. Walaupun interpretasi tersebut tidak mengikat secara juridis namun tetap dianggap penting karena dapat mengklarifikasi pengertian, sifat dan tujuan dari setiap hak. Sebagai contoh dalam menginterpretasikan Kovenan Ekonomi, Sosial, dan Budaya terutama pasal 2 (2) mengenai larangan diskriminasi, pasal 6 mengenai hak untuk bekerja, ${ }^{41}$ pasal 11 mengenai standar hidup yang cukup termasuk hak atas pangan, papan, dan air, pasal 12 mengenai hak untuk kesehatan, ${ }^{42}$ pasal 15

41 "...Private enterprise - national and multinational - while not bound by the Covenant, have a particular role to play in job creation, hiring policies, and non-discriminatory access to work", Lihat Committee on Economic, Social, and Cultural Rights, General Comment 18, Article 6: The Equal Right of Men and Women to the Enjoyment of All Economic, Social, and Cultural Rights Thirty-fifth Session sess., U.N. Doc. E/C.12/GC/18, 2006, para. 52. 
mengenai hak budaya, ${ }^{43}$ and hak yang berkaitan orang cacat, ${ }^{44}$ Komite Ekonomi, Sosial, dan Budaya menyatakan bahwa kewajiban yang timbul dalam pasal-pasal teresebut tidak hanya dibebankan pada negara tetapi juga aktor privat termasuk korporasi. Kewajiban-kewajiban aktor bukan negara tidak bersumber langsung dari Kovenan Ekonomi, Sosial, dan Budaya tetapi dari kewajiban negara untuk melindungi HAM (state obligation to protect) dimana negara berkewajiban untuk melindungi warganya dari pelanggaran yang dilakukan oleh individu atau institusi lain yang berada dalam wilayah jurisdiksinya. Dengan demikian, dapat disimpulkan bahwa pertanggungjawaban HAM korporasi bersumber pada akibat logis dari obligation to protect. Pelanggaran yang dilakukan korporasi tidak hanya menimbulkan pertanggungjawaban korporasi tetapi juga pertanggungjawaban negara. Dalam hal ini terjadi pertanggungjawaban ganda.

Metode terakhir adalah melakukan asumsi berdasarkan norma peremptory dan hukum kebiasaan internasional. Semua hak-hak yang terdapat dalam perjanjian internasional yang mempunyai karakter kebiasaan internasional atau jus cogens otomatis berlaku langsung terhadap korporasi tanpa mensyaratkan ratifikasi atau penerimaan dari suatu negara.

Penjelasan ini membuktikan bahwa walaupun korporasi tidak menjadi pihak dalam konvensi HAM tidak berarti bahwa konvensi tersebut tidak mengikat mereka. Singkat kata, pemberlakuan suatu perjanjian internasional terhadap aktor lain ditentukan oleh beberapa kondisi yang berlaku di negara tersebut seperti sifat dan tujuan dari hak-hak tersebut.

${ }^{42}$ Committee on Economic, Social, and Cultural Rights, General Comment 14, the Right to the Highest Attainable Standard of Health, Twenty-second session, 2000 sess., U.N. Doc. E/C.12/2000/4, 2000, para. 39, 42, and 48.

${ }^{43}$ Committee on Economic, Social, and Cultural Rights, General Comment 17, the Rights of Everyone to Benefit from the Protection of the Moral and Material Interest Resulting from Any Scientific, Literary, or Artistic Production of Which He or She Is the Author (Article 15, Paragraph I (C), of the Covenant) U.N. Doc. E/C.12/GC/17, 2006, para 55.

${ }^{44}$ Committee on Economic, Social, and Cultural Rights, General Comment 5, Persons with Disabilities Eleventh Session, 1994 sess., U.N. Doc. E/1995/22 at 19 1995, para. 11. 


\section{Instrumen-Instrumen Lain/Soft Law}

Konsep kewajiban HAM terhadap hak asasi manusia secara langsung diartikulasikan dalam instrument tidak mengikat yang sering kali disebut soft law. Instrument seperti rancangan 'Norms on the Responsibilities of Transnational Corporations and Other Business Enterprises with Regards to Human Rights' yang dikeluarkan Perserikatan Bangsa-Bangsa, ${ }^{45}$ ILO Tripartite Declaration of Principles concerning Multinational Enterprises and Social Policy, ${ }^{46}$ OECD Guidelines for Multinational Enterprises $^{47}$ dan Code of Conduct for European Enterprises operating in developing countries yang dikeluarkan oleh Uni Eropa merupakan contoh-contoh dari instrumen tidak mengikat yang bertujuan untuk memberikan batasan dalam melakukan kegiatan ekonomi.

\section{Kesimpulan}

Berdasarkan diskusi di atas, tampaknya ada kecenderungan untuk semakin diterimanya perdebatan mengenai horisontal HAM di mana semua pihak baik negara atau aktor lain bisa mengancam dan melanggar HAM. Hal ini terlihat dalam perkembangan HAM baik dalam tataran teoritis maupun praktis. Secara teoritis jelas terlihat bahwa telah terjadi pergeseran sifat HAM dari publik menjadi publik-privat, dari vertikal menjadi vertikal-horisontal. Walaupun masih terbatas sifatnya, perubahan tersebut juga mulai terlihat dalam tataran praktis hukum HAM internasional dimana upaya untuk mengakomodasi pelanggaran HAM oleh korporasi mulai diusahakan.

Secara general, diskusi yang sedang berlangsung mengenai aspek horisontal ini telah melahirkan sebuah hubungan baru yang kompleks antara publik dan privat yaitu privatisasi HAM. Privatisasi ini tidak menghapuskan 1999).

45 Andrew Clapham, "Human Rights in Private Sphere", (Oxford, Clarendon Press,

${ }^{46}$ It has been adopted by the governing body of the International Labour Organisation Office at its $204^{\text {th }}$ Session, November 1997.

47 The OECD Guidelines for Multinational Enterprises: Text, Commentary and Clarifications, Committe on International Investment and Multinational Enterprises, Organisation for Economic Co-operation and Development. 31 October 2001. 
kewajiban negara, karena kewajiban institusi privat terhadap HAM masih jatuh dalam lingkup kewajiban negara terhadap HAM.

Pada saat yang bersamaan, privatisasi HAM memberikan sifat publik terhadap hubungan pribadi antar individu. Dalam hal ini, sifat horisontal HAM tidak merujuk secara eksklusif pada hubungan antara pihak privat seperti dalam hukum perdata, juga tidak ditujukan untuk menggantikan hukum perdata. Sifat publik dalam relasi antar individu atau kelompok hanya berfungsi sebagai batasan dalam hubungan antar pribadi, di mana pelanggaran hak oleh individu atau institusi privat dapat dimintakan pertanggungjawaban negara. Salah satu analogi yang sering kali digunakan adalah kekerasan dalam rumah tangga. Walaupun keluarga memiliki karakter pribadi, hubungan antara anggota keluarga juga memuat sifat umum ketika terjadi kekerasan, oleh karena itu perlu campur tangan dari pemerintah. Demikian pula dalam hal hubungan antara pelaku bisnis dan individu lain. Ketika menerapkan prinsip-prinsip HAM dalam kerangka perusahaan, terlihat bahwa interaksi antara perusahaan, atau antara perusahaan dan individu bukan merupakan hubungan privat eksklusif. HAM berfungsi sebagai batas pemisah hubungan tersebut. Ini menyiratkan bahwa dalam rangka menjalankan bisnis, perusahaan harus memperhitungkan batas-batas yang diletakkan oleh HAM.

Sementara konstruksi ini menawarkan argumen logis untuk menerima tanggung jawab perusahaan dalam kerangka internasional, konstruksi ini masih menyisakan beberapa permasalahan seperti sampai sejauh mana kewajiban dan batasan kewajiban HAM korporasi yang patut untuk ditelusuri lebih lanjut. Artikel ini diharapkan menjadi pemicu diskusi-diskusi selanjutnya. 


\section{Daftar Pustaka}

\section{Instrumen Internasional \& Peraturan}

Constitution of the Republic of South Africa No. 108 of 1996. 1996.

Convention on the Elimination of All Forms of Discrimination against Women. Adopted by the General Assembly of the United Nations on 18 December 1978 and entered into force on 3 September 1981.

Committee on Economic, Social, and Cultural Rights. General Comment 5, Persons with Disabilities Eleventh Session, 1994 sess., U.N. Doc. E/1995/22 at 191995.

Committee on Economic, Social, and Cultural Rights. General Comment 14, the Right to the Highest Attainable Standard of Health. Twenty-second session, 2000 sess., U.N. Doc. E/C.12/2000/4, 2000 .

Committee on Economic, Social, and Cultural Rights. General Comment 17, the Rights of Everyone to Benefit from the Protection of the Moral and Material Interest Resulting from Any Scientific, Literary, or Artistic Production of Which He or She Is the Author (Article 15, Paragraph 1 (C), of the Covenant) U.N. Doc. E/C.12/GC/17, 2006.

Committee on Economic, Social, and Cultural Rights. General Comment 18, Article 6: The Equal Right of Men and Women to the Enjoyment- of All Economic, Social, and Cultural Rights Thirty-fifth Session sess., U.N. Doc. E/C.12/GC/18, 2006.

The OECD Guidelines for Multinational Enterprises: Text, Commentary and Clarifications. Committe on International Investment and Multinational Enterprises, Organisation for Economic Co-operation and Development. 31 October 2001.

Vienna Convention on the Law of Treaties. Adopted on 22 May 1969, entry into force on 27 January 1980. 


\section{Kasus}

Trial Chamber II International Tribunal for Yugoslavia. Prosecutor V. Anto Furundzija. Case No. IT-95-17/1, Judgment of 10 December 1998. 1998.

\section{Buku}

Charlesworth, Hilary, and Christine Chinkin. The Boundaries of International Law; a Feminist Analysis. Manchester: Jurist Publishing, Manchester University Press, 2000.

Chirwa, Danwood Mzikenge. Towards Binding Economic, Social, and Cultural Rights Obligations of Non-State Actors in International and Domestic Law: A Critical Survey of Emerging Norms. Dissertation. University of Western Cape, 2005.

Clapham, Andrew. Human Rights in Private Sphere. Oxford: Clarendon Press, 1999. . Human Rights Obligations of Non-State Actors. Oxford: Oxford University Press, 2006.

Dembour, Marie-Bénédicte. Who Believes in Human Rights? Reflections on the European Conventions. Cambridge: Cambridge University Press.

Emberland, Marius. The Human Rights of Companies: Exploring the Structure of Echr Protection. Oxford: Oxford University Press, 2006.

Freeman, M.D.A. Lloyd's Introduction to Jurisprudence. 7th ed. London: Sweet \& Maxwell, 2001.

Hayden, Patrick. The Philosophy of Human Rights. St. Paul: Paragon House, 2001.

Higgins, Rosalyn. Problems and Process: International Law and How We Use It. Oxford: Clarendon Press, 1994.

Hodgson, Dauglas. Individual Duty within a Human Rights Discourse. Ashgate, 2003.

Kelley, David. A Life of One's Own: Individual Rights and the Welfare State. Cato Institute, 1998. 
Marx, Karl. Critique of Hegel's Philosphy of Rights. Trans. Annette Jolin and Joseph O'Malley. Ed. Joseph O'Malley. Cambridge: Cambridge University Press, 1943-44 (written) \& 1970 (published).

Nowak, Manfred. Introduction to the International Human Rights Regime. Leiden: Martinus Nijhoff Publishers, 2003.

Sinha, Manoj Kumar. Enforcement of Economic, Social, and Cultural Rights. New Delhi: Nice Printing Press, 2006.

Steiner, Henry J., Philip Alston, and Ryan Goodman. International Human Rights in Context: Law, Politics, Morals: Text and Materials. 3th ed. Oxford: Oxford University Press, 2008.

Unger, Aryeh L. Constitutional Development in the Ussr: A Guide to the Soviet Constitutions. London: Methuen, 1984.

\section{Bab dalam Buku}

Alkema, Evert Albert. "The Third Party Applicability or 'Drittwirkung' of the European Convention on Human Rights" Protection of Human Rights. The European Dimension. Ed. Herbert Petzold Franz Matscher. Berlin: Carl Heymanns Verlag, 1988.

An-Na'im, Abdullahi Ahmed. "Conclusion." Human Rights in CrossCultural Perspective: A Quest for Consensus. Ed. Abdullahi Ahmed An-Na'im. Pennyslvania: University of Pennsylvania Press, 1995.

Goodhart, Michael. "Human Rights and Non-State Actors." Non-State Actors in the Human Rights Universe. Eds. George Andreopoulos, Zehra F. Kabasakal Arat and Peter Juviler. Bloomfield: Kumarian Press, Inc., 2006.

"Human Rights and Non-State Actors: Theoritical Puzzles." Non-State Actors in the Human Rights Universe. Eds. George Andreopoulos, Zehra F. Kabasakal Arat and Peter Juviler. Bloomfield: Kumarian Press, Inc, 2006.

Teubner, Gunther. "Global Bukowina': Legal Pluralism in the World Society." Global Law without State. Ed. Gunther Teubner. Brookfield: Dartmouth, 1997. 
Woolman, Stuart. "Application." Constitutional Law of South Africa. Eds. Matthew Chaskalson Jenet Kentridge, et al. 1st ed. Cape Town: Juta \& Co. Ltd, 1999.

\section{Artikel Jurnal}

Chemerinsky, Erwin. "Rethingking State Action " Northwestern University Law Review 80.3 (1985).

Hessbruegge, Jan Arno. "Human Rights Violations Arising from Conduct of Non-State Actors." Buffalo Human Rights Law Review 11.21 (2005).

Marx, Karl. "On the Jewish Question." Deutsch-Französische Jahrbücher (1844).

Pollis, Adamantia. "Cultural Relativism Revisited: Through a State Prism." Human Rights Quarterly 18.2 (1996): 316 - 344.

. "Towards a New Universalism: Reconstruction and Dialogue." Netherland Quarterly of Human Rights 16.1 (1998).

Teubner, Gunther. "The Anonymous Matrix: Human Rights Violations by 'Private' Transnational Actors." The Modern Law Review 69.3: $327-346$. 